
About IJMA [last updated July, $\left.1^{\text {st }}, 2021\right]$

$\checkmark$ International Journal of Medical Arts is the Official Journal of the Damietta Faculty of Medicine, AlAzhar University, Egypt

$\checkmark$ It is an International, Open Access, Double-blind, Peer-reviewed Journal

$\checkmark$ Published four times a year

$\checkmark$ The First Issue was published in July 2019

$\checkmark$ Published under the following license: Creative Commons Attribution-ShareAlike 4.0 International Public License (CC BY-SA 4.0). It had updated from the Creative Commons license [CC BY] in volume 2, Issue 4, October 2020 About IJMA

$\checkmark$ The Egyptian Knowledge Bank hosts the web site of IJMA

$\checkmark$ The Egyptian Knowledge Bank supports IJMA

$\checkmark$ IJMA follows the regulations of the International Committee of Medical Journal Editors

$\checkmark$ IJMA is indexed in the "Directory of Open Access Journals" [15 January 2021].

$\checkmark$ IJMA is indexed in JGate [29-6-2021]

$\checkmark$ IJMA is a member of the International Society of Managing and Technical Editors

$\checkmark$ Listed in "Index Copernicus", "Publons", "Academic resource index [ResearchBib]", "Electronics journal library", "Eurasian Scientific Journal Index", and "Citefactor"

$\checkmark$ IJMA introduced to the search engine [BASE] through DOAJ
Click image to reach the page

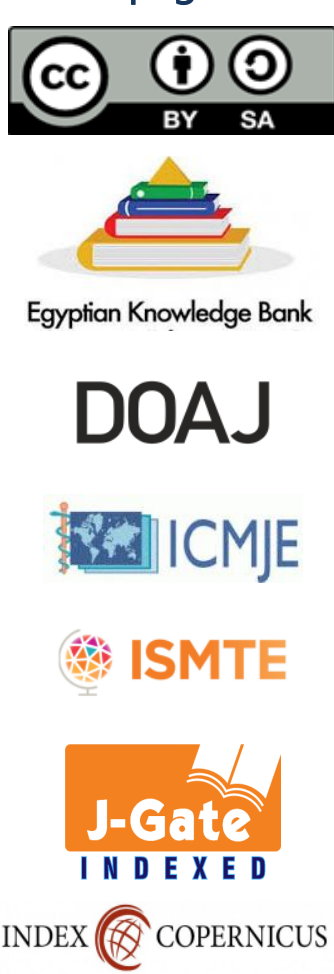

publons

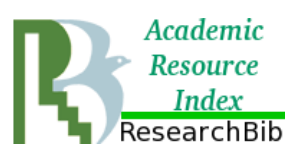

\section{EZ3 \\ .}

ESJII

CiteFactor

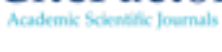

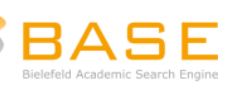




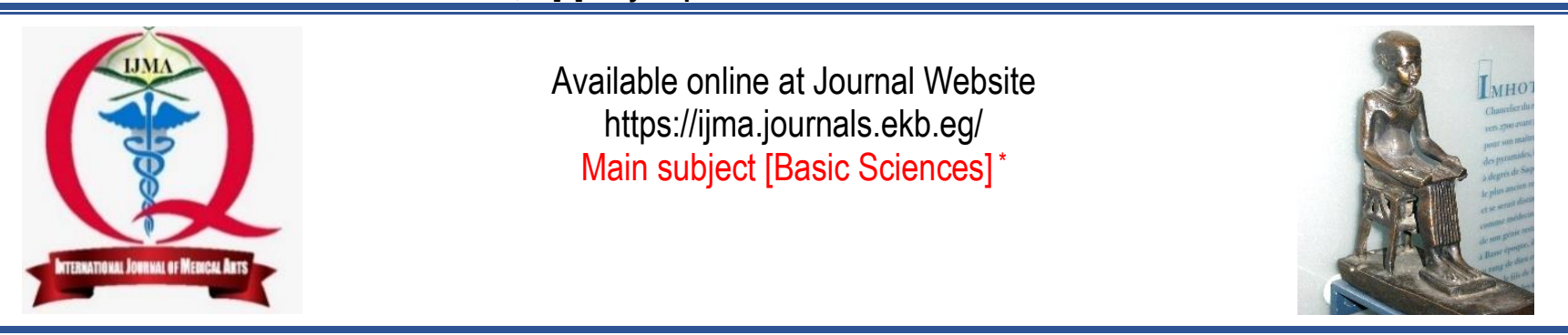

Original Article

\title{
Risk of Vibrio Transmission Linked to Consumption and Contact with Water in Benin.
}

\author{
Bawa Boya [1], Haziz Sina [1], Théodora A. Ahoyo [2], Victorien T Dougnon [3], Akim Socohou [1], Nana Mariama \\ Maman [3], Didier Bompangue [4], Lamine Saïd Baba Moussa [1] \\ ${ }^{1}$ Laboratory of Biology and Molecular Typing in Microbiology [LBTMM]. University of Abomey-Calavi, 05 BP 1604 Cotonou, Benin \\ ${ }^{2}$ Engineering of Human Biology / Polytechnic School of Abomey-Calavi [EPAC], University of Abomey-Calavi, Benin \\ ${ }^{3}$ Research Unit in Microbiology, Application and Pharmacology of Natural Substances [URMAPha], University of Abomey-Calavi, Benin \\ ${ }^{4}$ Department of Microbiology, Faculty of Medicine, University of Kinshasa, Kinshasa, Democratic Republic of Congo
}

Corresponding author: Haziz Sina

Email: sina.haziz@gmail.com.

Submission date: March 30, 2021; Revision date: June 16, 2021 ; Acceptance date: June 16, 2021.

\section{ABSTRACT}

Background: Vibrio infections have increased in Benin, and this phenomenon is expected to increase due to climate change, increased consumption of contaminated water and the number of people who are immunocompromised.

The aim of the work: The objective of this study was to evaluate the risk of Vibrio transmission linked to the use of contaminated water in Benin.

Methodology: Water samples [ $n=220]$ were analyzed to isolate Vibrio strains using their biochemical and cultural characteristics. The species were identified by the Polymerase Chain Reaction technique by monitoring the search for genes encoding the cholera toxin of Vibrio cholerae [ctxA and ctxB] and the direct thermostable and thermostable hemolysins linked to Vibrio parahaemolyticus [tdh and trh].

Results: Among the 220 collected samples, the biochemical tests revealed 86 strains of Vibrio species; Vibrio cholerae [35\%], Vibrio parahaemolyticus [18.60\%] and Vibrio alginolyticus [13.95\%] were identified using molecular tool. The presence of genes encoding the main virulence factors of the strains studied. Thus $6.67 \%, 10 \%$ and $3.33 \%$ of the strains of Vibrio cholerae respectively contain the toxins ctxA, ctxB and the couple ctxA and ctxB. Likewise, the Vibrio parahaemolyticus strains contain $12.5 \%$ tdh toxins and $31.25 \%$ [tdh and trh]. The search for genes [tdh and trh] in Vibrio alginolyticus was also negative.

Conclusion: Epidemics can be triggered by natural or fabricated events that contaminate drinking water or compromise access to safe drinking water and sanitation. The incidence of vibriosis is increasing, perhaps in part because of the spread of Vibrio species promoted by climate change and increasing water temperature.

Keywords: Water; Vibrio species; Polymerase Chain Reaction; Virulence Genes; Bacterial Resistance.

This is an open-access article registered under the Creative Commons, ShareAlike 4.0 International license [CC BY-SA 4.0] [https://creativecommons.org/licenses/by-sa/4.0/legalcode.

Citation: Boya B, Sina H, Ahoyo TA, Dougnon VT, Socohou A, Maman NM, Bompangue D, Baba-Moussa L. Risk of Vibrio transmission linked to consumption and contact with water in Benin. IJMA 2021; 3 [3] July-September: 1624-1635 [DOI: 10.21608/IJMA.2021.67136.1289].

* Main subject and any subcategories have been classified according to the research topic. 


\section{INTRODUCTION}

Cholera, a disease of wars, famines and natural disasters that seemed to belong to history, is unfortunately still relevant around the world [1]. This disease is caused by ingesting food or water contaminated with the bacillus Vibrio cholerae, belonging to the genus Vibrio. In 1970, the Seventh Cholera Pandemic first hit Africa ${ }^{22]}$. Since 2000, the incidence of cholera has gradually increased with a cumulative number of cases increased by $43 \%$ [3].

In Benin, the cholera epidemic appeared in 1970. Since then, cholera epidemics have become almost annual and generally occur at the end of the rainy season [4]. Between 2004 and 2013, epidemiological surveillance notified 5,432 cases with 48 deaths [i.e. a case fatality rate of $0.9 \%$ ].

Although from 2012 to 2014 there was a decrease in the number of notified cases, in 2016 there was an upsurge in cholera where Benin recorded 874 cases including 13 deaths, i.e. a fatality of $1.96 \%$ [5].

The Vibrio transmission factors are well identified and mainly concerns water and food in endemic countries. The marine environment is cited as a potential vector for infections of non-cholera vibrios. This includes seafood [fish, shellfish and crustaceans], swimming and more generally all contact with the coastal environment. The density of these vibrios in the environment changes depending on various environmental factors such as water temperature, salinity, $\mathrm{pH}$, turbidity, and chlorophyll A. However, only 12 of these species are considered pathogenic for human while the others were cultivated mainly from different species of aquatic animals and marine environment ${ }^{[6-8]}$.

Currently, non-cholera Vibrio species [spp.] play an important role as causative agents of sporadic cases of cholera-like illness and isolated epidemics associated with the consumption of contaminated water ${ }^{[9]}$. Recent work in India and Bangladesh has shown that there are epidemics caused by non-cholera Vibrio spp. isolated in an aquatic environment [9]. However, due to its continual expansion, both inside and outside hospitals, each study of the virulence factors of Vibrio spp. analyzing a particular situation makes it possible to not only follow and understand its evolution but also to define control strategies at the hospital or community level. Indeed, the pathogenic Vibrio species are not always so. The majority of environmental strains lack the colonizing factors necessary for adhesion and penetration of toxins and/or other virulence determinants necessary to initiate disease. Nevertheless, little is known about the presence of Vibrio in bodies of water in Benin. However, the lagoon regions of Benin are considered cholera endemic areas. Studies have shown that pathogens, Vibrio cholerae 01 in particular, can be viable and potentially pathogenic but in a dormant state during periods of unfavorable conditions in the aquatic environment [10]. Thus, this study aimed at evaluating the risk of Vibrio transmission linked to uses of potentially contaminated water in Benin.

\section{MATERIAL AND METHODS}

\section{Study area}

The study was carried out in 11 cholera endemic communes in Benin [11]. These are Abomey-Calavi, Cotonou, Porto-Novo, Seme-Kpodji, Dassa-Zoumé, Savalou, Djougou, Sô-Ava Parakou, Athiémé and Aguégué [Figure 1].

\section{Sampling and samples collection}

The sample size was determined using Schwartz's formula with a $95 \%$ confidence level and a $5 \%$ margin of error and a prevalence of Vibrio cholerae in water [14.8\%] according to Madoroba and Momba [12]. This gave us a minimum height of 195 samples. A $13.4 \%$ increase was made and gave a final size of 220 samples. Per targeted endemic commune, 20 water samples were collected from June to October 2018. A total of 220 water samples were collected using the Rodier technique [13]. Briefly, $500 \mathrm{ml}$ of water was taken at about $0.5 \mathrm{~cm}$ from the water surface in sterile glass vials.

\section{Physico-chemistry parameter of sampled waters}

The $\mathrm{pH}$ and the temperature of these samples were measured with respectively an electronic $\mathrm{pH}$ meter $[\mathrm{HI}$ 96107 instruments from Hanna] and a digital thermometer [VWR EU 620-2132 NA 98000-162]. After collection, samples were transported to the laboratory in coolers containing thermal accumulators $\left[4^{\circ} \mathrm{C}\right]$.

\section{Isolation of Vibrio spp from water samples}

The isolation was carried out according to the method of Rodier et al. [13]. Each water sample [10 ml] was enriched in an alkaline nutrient broth [alkaline peptone water at $30 \mathrm{~g}$ I I of $\mathrm{NaCl}$ ] for 24 hours at $37^{\circ} \mathrm{C}$. The haze that will develop on the surface of this medium will be seeded on Thiosulfate Citrate Bile Sucrose [TCBS, Bio-Rad@]. After $24 \mathrm{~h}$ of incubation at $37^{\circ} \mathrm{C}$, each presumptive Vibrio characteristic colonies was isolated and sub cultured on $2 \% \mathrm{NaCl}$ alkaline nutrient agar [Biorad], then incubated $24 \mathrm{~h}$ at $37^{\circ} \mathrm{C}$ to obtain pure strains. Identification was completed according to standard bacteriological methods [oxidase test, TSI test, 
serogrouping and hemolysis test on blood agar medium].

\section{Molecular identification of Vibrio's strains and detection of virulence genes}

The total DNA isolated Vibrio strains was extract from bacterial culture using heating method [14]. Thus, a $24 \mathrm{~h}$ old Vibrio culture was suspended on sterile distillated water [500 $\mathrm{\mu l}$ ] heated in a dry bath $\left[95^{\circ} \mathrm{C}\right.$ for $\left.15 \mathrm{~min}\right]$ then centrifuged $[12,000 \mathrm{rpm}$ for $5 \mathrm{~min}]$. To a volume of supernatant, an equivalent volume of fresh ethanol $\left[4^{\circ} \mathrm{C}\right]$ was added in ice. After $15 \mathrm{~min}$, the precipitate was recovered by centrifugation [12000 rpm for $5 \mathrm{~min}$ ] and suspended in $50 \mu \mathrm{l}$ of DNase free pure water. The isolated Vibrio species were confirmed molecularly using previously describes methods [15-18].

\section{Detection of Virulence Genes among the isolated Vibrio's strains}

Further characterization was performed to investigate the presence genes encoding virulence factors on $V$. cholerae [ctxA and ctxB] and V. parahaemolyticus [tdh and trh] using appropriate primers sequences [19-21]. Positive control, for the confirmation and characterization of virulence factors in Vibrio cholerae were obtain from the National Laboratory of Benin and Research and Training Unit on Ecology and the Control of Infectious Diseases [URF-ECMI] of the DRC. The primers used in this study and the target genes are summarized in [Table 1].

\section{Data analysis and processing}

The averages were calculated from the results using the Excel 2016 spreadsheet. Graph-Pad Prism 8 was used to make graphs. Following identification, a simple correspondence factorial analysis was performed to determine the correlation between species [CFA] with the "CA" function of the "Facto Mine R" package [22] using the software R 3.4.0 [23].

\section{RESULTS}

\section{Physico-chemistry parameter of water samples}

The average values of the temperature and the $\mathrm{pH}$ of the water obtained from the lakes, lagoons and estuaries are presented in [Table 2].

The average $\mathrm{pH}$ values recorded were between $6.11 \pm 0.03$ and $7.52 \pm 0$. The lowest $\mathrm{pH}$ [acidic $\mathrm{pH}$ ] was obtained in the communes of Athiémé [6.11 \pm 0.03 ] and Sèmè-Podji [6.34 \pm 0.03 ] while the highest $\mathrm{pH}$ [alkaline] was recorded in the town of Savalou. Likewise, the average temperature values recorded were between $27.85 \pm 0.1$ [Savalou] and $32.91 \pm 1.7^{\circ} \mathrm{C}$ [Parakou].

\section{Microbial contamination of the water samples according to the collection places}

The results of the incidence of vibrio's and other strains in the different communes are summarized in [Figure 2 and 3]. Thus, it appear that the collected water samples were contaminated by Citrobacter freundii [17.73\%], Vibrio spp [32.73\%], Proteus spp [20.45\%], Salmonella spp [28.18\%] and Escherichia coli [23.18\%]. The lowest rate of Vibrio spp [15\%] was obtained in the communes of Athiémé and SèmèPodji while a high rate of Vibrio spp [65\%] was obtained in the commune of Savalou. In addition, Salmonella sp. was highly identified $[60 \%]$ in the samples collected in the municipality of Aguégué. Concerning the Escherichia coli strains, they were highly isolated from the samples collected in the northern [85\% for Parakou and 55\% for Djougou] part of the country.

\section{Molecular Identification of Vibrio species}

Of the 86 strains of Vibrio isolated from sampled waters, $13.95 \%$ belong to the species V. alginolyticus, $18.60 \%$ to the species V. parahaemolyticus, $35 \%$ to the species $V$. cholerae and $32.56 \%$ to the species Vibrio spp. [Table 3] shows the distribution of Vibrio species identified by PCR according to the municipalities.

The correlation between identified species seems weak except between $V$. alginolyticus and $V$. parahaemolyticus [Figure 4]. Analyzing this figure, the first two axes explain $70 \%$ of the total variability. On the first axis of the correlation circle: the variables $V$. alginolyticus and $V$. parahaemolyticus have a strong correlation with this axis.

The two variables contribute $97 \%$ to the formation of this axis and are very well represented. On the first axis of the individuals' cloud, an axis is strongly determined by the commune of Djougou that contributes $65 \%$ to its formation. Globally, Djougou is the city for which the variables $V$. alginolyticus and $V$. parahaemolyticus have the highest values. In the samples of Savalou, Parakou and AbomeyCalavi, high values for Vibrio cholerae and Vibrio spp. were observed while at Porto-Novo, the values for the sames strains were low. This explain why Porto-Novo is opposed to Savalou, Abomey-Calavi on axis 2 [Figure 5].

\section{Distribution of virulence factors in Vibrio species.}

The genes encoding major virulence factors, cholera toxin of $V$. cholerae [ctxA and ctxB] and the direct and thermostable heat-stable hemolysins of $V$. parahaemo- 
Iyticus [tdh and trh] were detected in strains of $V$. cholerae and V. parahaemolyticus which we characterized by PCR. Thus, the characterized Vibrio cholerae strains harbor the gene encoding for ctxA [6.67\%], ctxB [10\%] and the couple ctxA-ctxB [3.33\%] toxins [Figure 6].
Likewise, the $12.5 \% \quad V$. parahaemolyticus strains contain the encoding for th toxins and $31.25 \%$ of them harbor both tdh and trh [Figure 7]. The search for genes [tdh and trh] in $V$. alginolyticus was also negative.

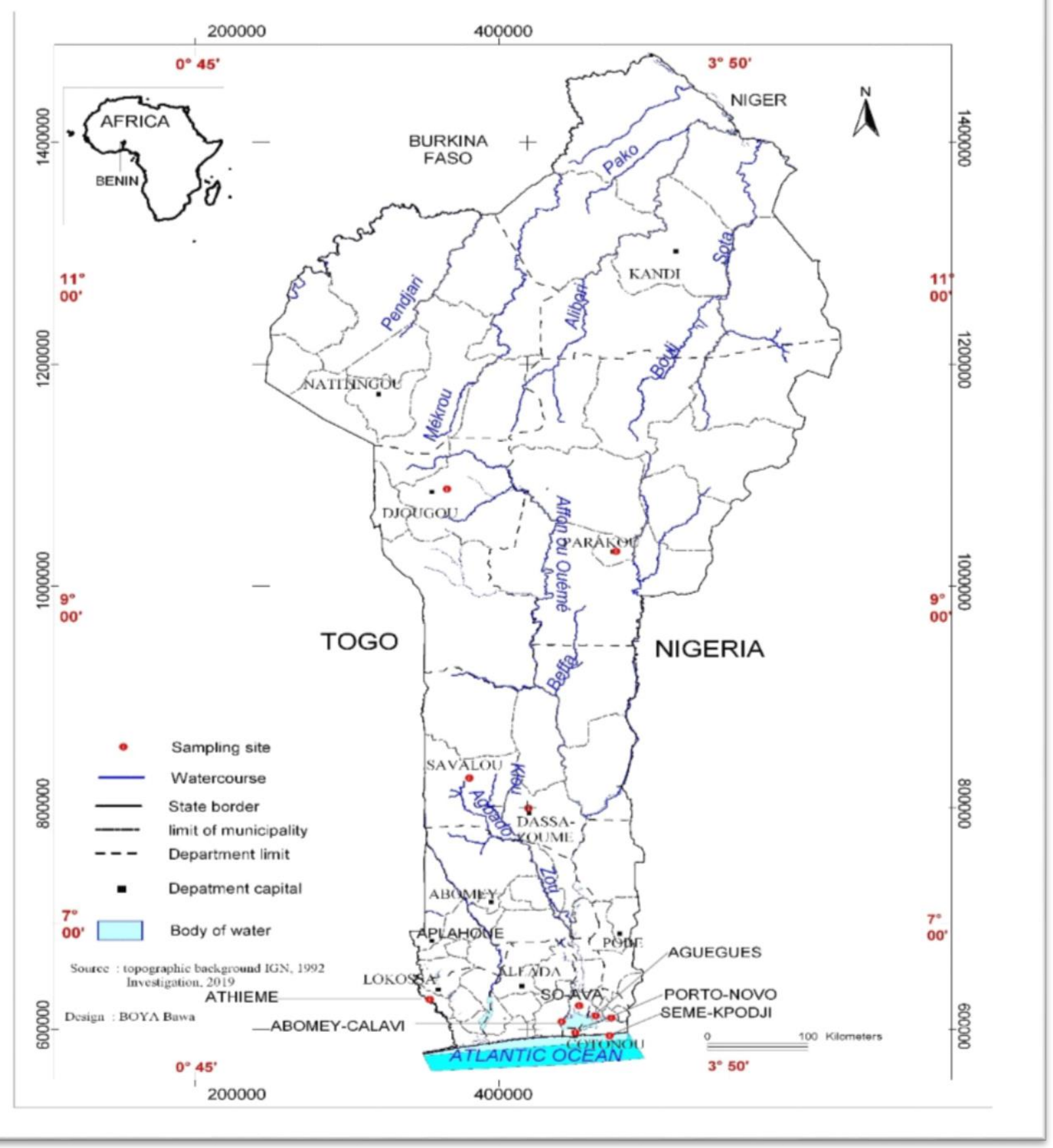

Figure [1]: Map showing the sample's areas 


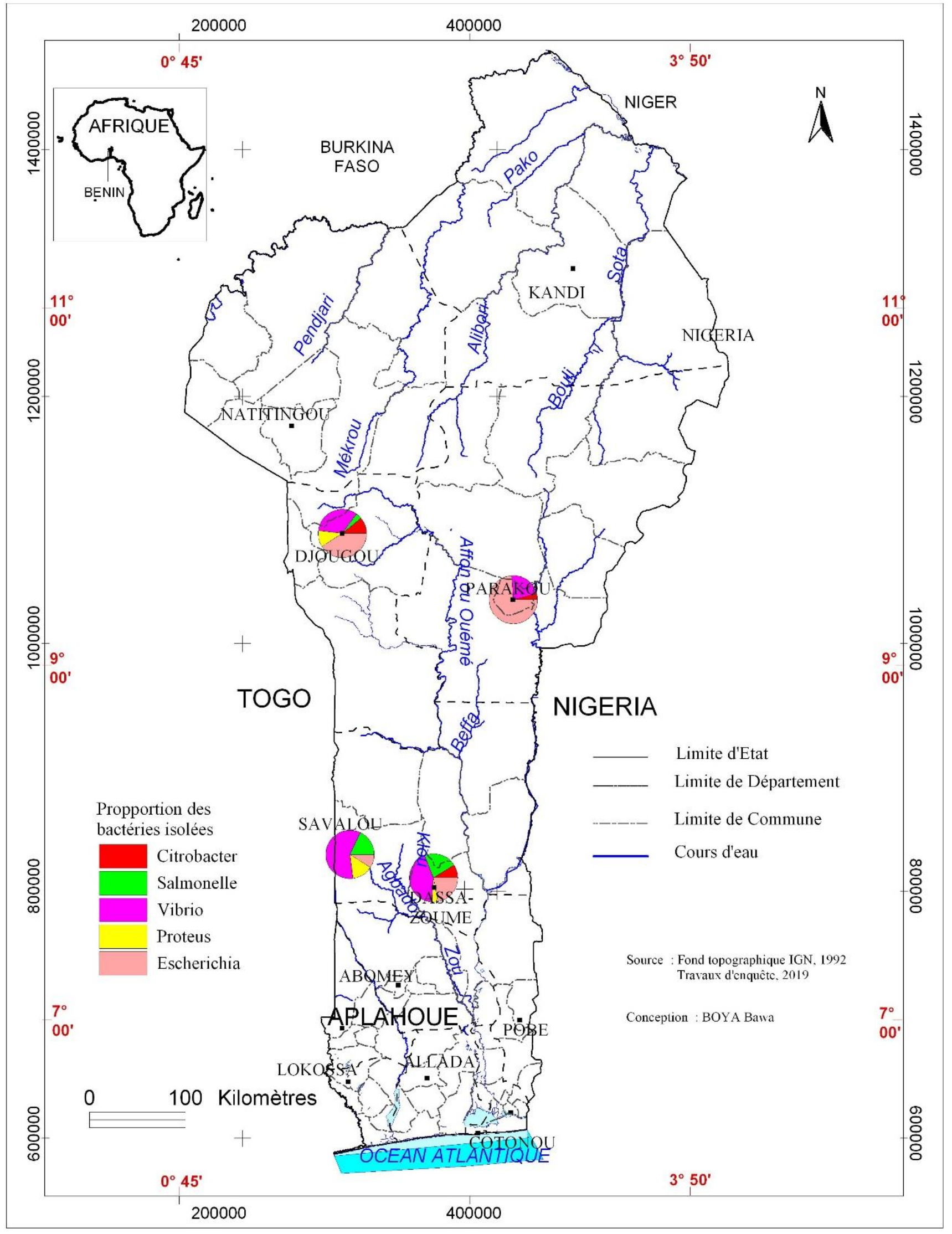

Figure [2]: Distribution of strains identified by biochemical tests in northern Benin 


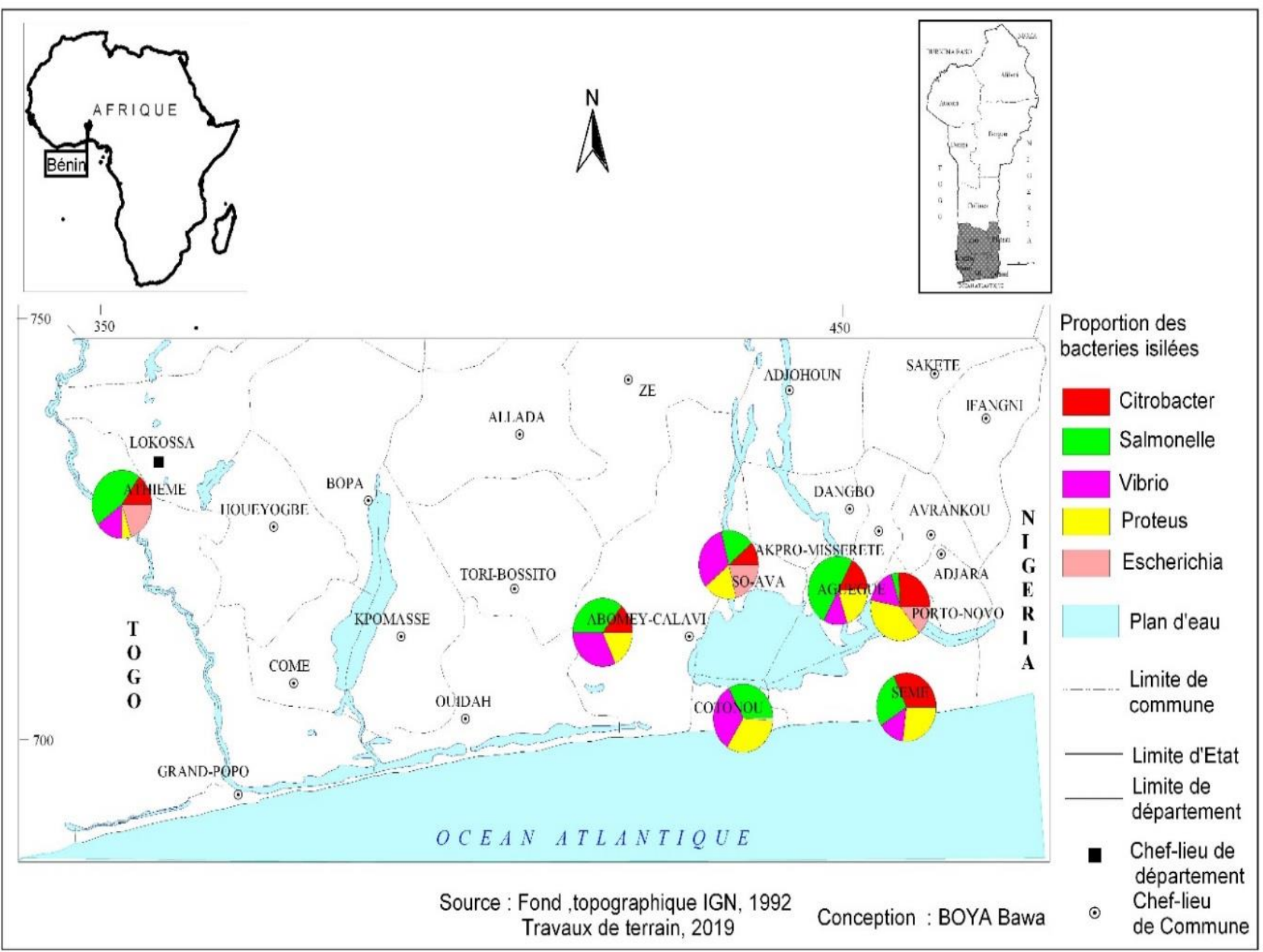

Figure [3]: Distribution of strains identified by biochemical tests in southern Benin

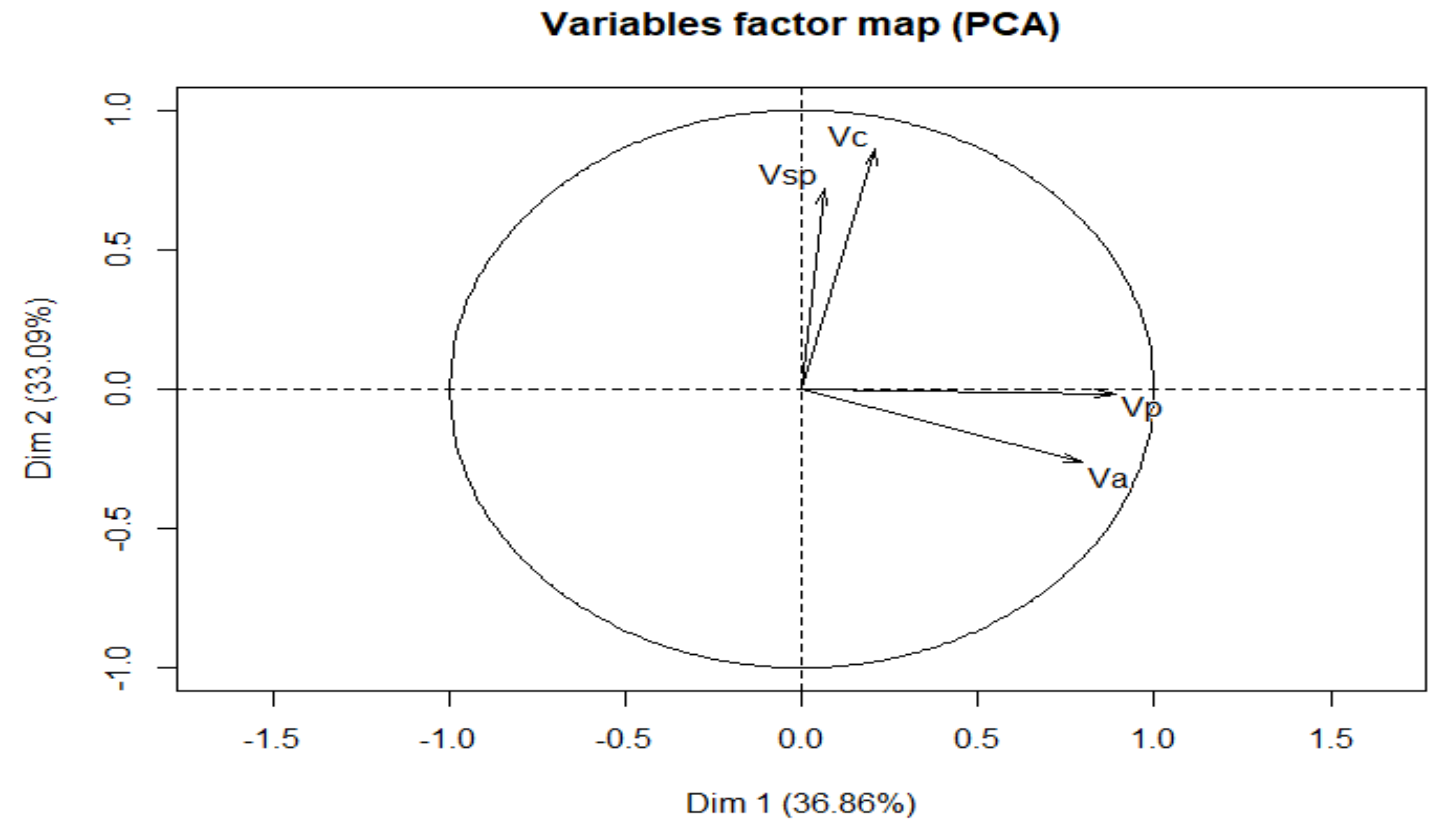

Figure [4]: Grouping of species identified according to their similarity 


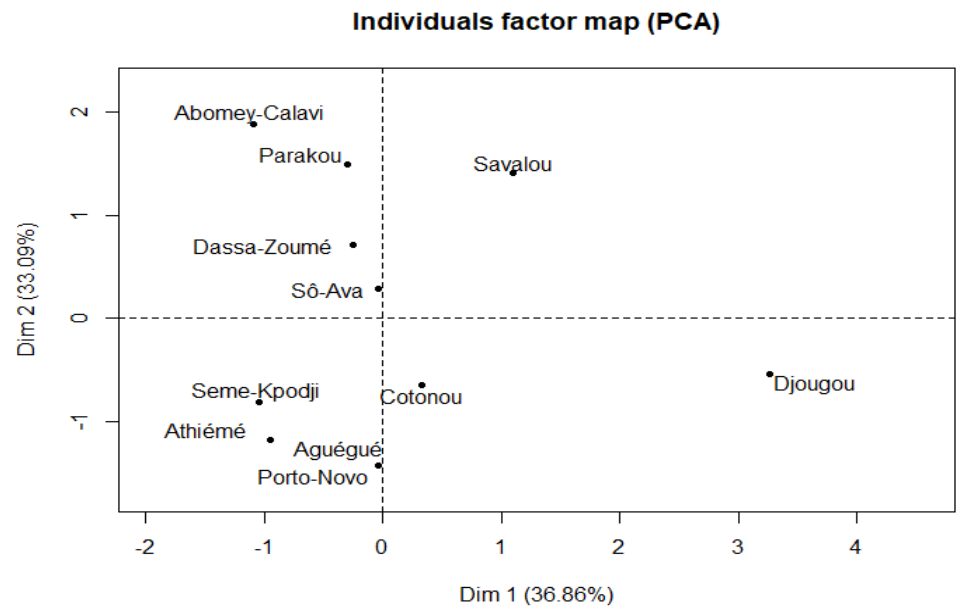

Figure [5]: Grouping of genera and species identified according to the municipalities

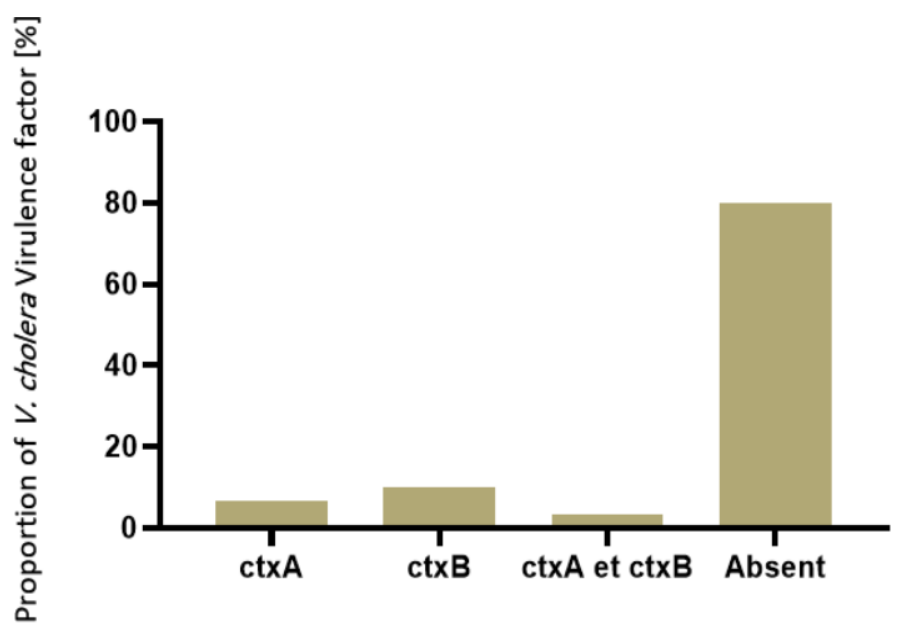

Virulence factor

Figure [6]: Percentage of Vibrio cholerae species carrying genes encoding cholera toxin.

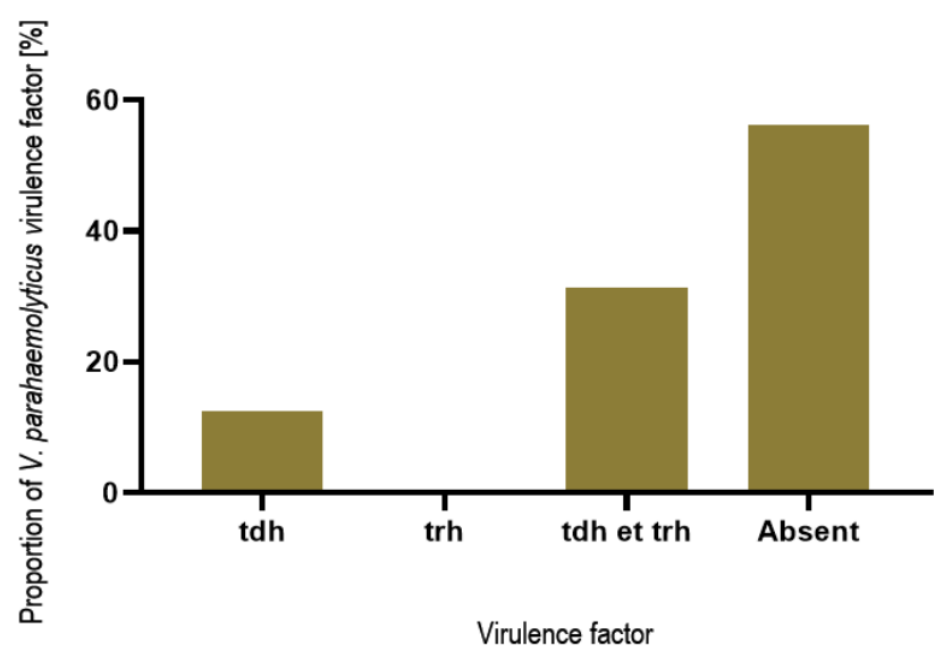

Figure [7]: Percentage of Vibrio parahaemolyticus species harboring genes encoding the hemolysins thh and trh. 
Table [1]: List of used primers for the molecular characterization of Vibrio strains

\begin{tabular}{|c|c|c|c|}
\hline Targets genes & Primers & Sequence $\left[5^{\prime}-3^{\prime}\right]$ & Size \\
\hline \multirow{2}{*}{ 16S/23S ISR } & VCM-F & 5'-TTAAGCSTTTTCRCTGAGAATG- 3' & \multirow{2}{*}{$295-310 \mathrm{pb}$} \\
\hline & VCM-R & 5'AGTCACTTAACCATACAACCC G- 3' & \\
\hline \multirow{2}{*}{ Pr72H } & VP32 & 5'-CGAATCCTTGAACATACGCAGC- 3' & \multirow{2}{*}{$320-387 \mathrm{pb}$} \\
\hline & VP33 & 5'-TGCGAATTCGATAGGGTGTTA ACC-3' & \\
\hline ToxR & $\begin{array}{l}\text { ToxR } 4 \\
\text { ToxR } 7\end{array}$ & $\begin{array}{l}\text { 5'-GTCTTCTGACGCAATCGTTG-3' } \\
\text { 5'-ATACGAGTGGTTGCTGTCATG- 3' }\end{array}$ & $368 \mathrm{pb}$ \\
\hline $\operatorname{ctx} A$ & $\begin{array}{l}\text { CTX2 } \\
\text { CTX3 }\end{array}$ & $\begin{array}{l}\text { 5'-CGGGCAGATTCTAGACCTCCTG- 3' } \\
\text { 5'-CGATGATCTTGGAGCATTCCCAC- 3' }\end{array}$ & $564 \mathrm{pb}$ \\
\hline $\operatorname{ctx} B$ & $\begin{array}{l}\text { CTX7 } \\
\text { CTX9B }\end{array}$ & $\begin{array}{l}\text { 5'-GGTTGCTTCTCATCATCGAACCAC- 3' } \\
\text { 5'-GATACACATAATAGAATTAAGGATG- 3' }\end{array}$ & $460 \mathrm{pb}$ \\
\hline$t d h$ & $\begin{array}{l}\text { L.tdh } \\
\text { R.tdh }\end{array}$ & $\begin{array}{l}\text { 5'-GTAAAGGTCTCTGACTTTTGGAC- 3' } \\
\text { 5'-TGGAATAGAACCTTCATCTTCACC- } 3 \text { ' }\end{array}$ & $269 \mathrm{pb}$ \\
\hline trh & $\begin{array}{l}\text { L.trh } \\
\text { R.trh }\end{array}$ & $\begin{array}{l}\text { 5'-TTGGCTTCGATATTTTCAGTA TCT- 3' } \\
\text { 5'CATAACAAACATATGCCCATTTCCG-3' }\end{array}$ & $500 \mathrm{pb}$ \\
\hline
\end{tabular}

Table [2]: Physicochemical parameters of water samples

\begin{tabular}{|l|c|c|}
\hline \multirow{2}{*}{ Communes } & \multicolumn{2}{|c|}{ Parameters } \\
\cline { 2 - 3 } & $\mathrm{pH}$ & Temperature \\
\hline Abomey-Calavi & $7.13 \pm 0.2$ & $31.4 \pm 2$ \\
\hline Aguégué & $7.17 \pm 0.03$ & $28.35 \pm 0.5$ \\
\hline Athiémé & $6.11 \pm 0.03$ & $28 \pm 0$ \\
\hline Cotonou & $7.2 \pm 0.9$ & $29 \pm 1.4$ \\
\hline Sô-Ava & $7.33 \pm 0$ & $29.3 \pm 0$ \\
\hline Porto-Novo & $7.30 \pm 0.2$ & $28.7 \pm 0$ \\
\hline Sèmè-Podji & $6.34 \pm 0.3$ & $30.09 \pm 2.5$ \\
\hline Parakou & $7.25 \pm 0.4$ & $32.91 \pm 1.7$ \\
\hline Djougou & $7.21 \pm 0.3$ & $29.14 \pm 0.9$ \\
\hline Savalou & $7.52 \pm 0$ & $27.85 \pm 0.1$ \\
\hline Dassa & $7.24 \pm 0.2$ & $31.96 \pm 1.4$ \\
\hline
\end{tabular}

Table [3]. Distribution of Vibrio species identified by PCR according to the municipalities

\begin{tabular}{|l|c|c|c|c|}
\hline \multirow{2}{*}{ Communes } & \multicolumn{4}{|c|}{ Species [\%] } \\
\cline { 2 - 5 } & V. cholerae & V. parahaemolyticus & V. alginolyticus & Vibrio spp \\
\hline Abomey-Calavi & 16,67 & 0 & 0 & 17.86 \\
\hline Aguégué & 0 & 0 & 8.33 & 7.14 \\
\hline Athiémé & 0 & 0 & 8.33 & 7.14 \\
\hline Cotonou & 6.67 & 6.25 & 16.67 & 7.14 \\
\hline Dassa-Zoumé & 20.00 & 12.5 & 0 & 0 \\
\hline Djougou & 10.00 & 37.5 & 25 & 7.14 \\
\hline Parakou & 13.33 & 12.5 & 0 & 17.86 \\
\hline Porto-Novo & 3.33 & 12.5 & 8.33 & 0 \\
\hline Savalou & 16.67 & 12.5 & 16.67 & 17.86 \\
\hline Seme-Kpodji & 6.67 & 6.25 & 0 & 0 \\
\hline Sô-Ava & 6.67 & 0 & 16.67 & 17.86 \\
\hline
\end{tabular}




\section{DISCUSSION}

The physico-chemical characteristics measured show a variation from one municipality to another. Issola et al. [24] have reported the variation in temperature we observed in our study. Those authors explain that the spatial variations in water temperature originate in border environments. In addition, the high values observed for the temperature measurement can be explained by the effect of global warming on the coastal lagoon as no source of hot residual water discharge has been recorded. This explanation refers to the study by Boko et al. ${ }^{[25]}$ on the issue of climate change in Benin, stressing that the temperature rose by $0.9^{\circ} \mathrm{C}$ after 2010.

Indeed, the average depth of the lagoon, of the order of 0.5 to $4 \mathrm{~m}$, the mixing of the waters due to the winds, fishing activities, navigation on the lagoon water. In addition, the sun's rays have the ability to pass through this small thickness of water to heat it evenly [26-27].

The average $\mathrm{pH}$ of 7.52 of the waters shows that these waters are basic. These values are of the same order as those observed in the surface waters of the lagoons of in Brazil from 1984 to 2000 [28].

The lower $\mathrm{pH}$ values observed during our study reflect the direct effects of acidic water. Indeed, as Kouassi [26] showed, the spatial and temporal variations in salinity, depending on the relative importance of continental and oceanic inputs, conditioning the seasonal $\mathrm{pH}$ variation. Thus, periods of high salinity correspond to rather basic waters and to sequences of strong continental influences weakly acidic waters. This shows that the oceanic influence on lagoons and lakes is preponderant over the continental influence for most of the year.

Vibrio spp is one of microorganisms that primary habitats are aquatic ecosystems [29]. In this study, $32.73 \%$ water samples was positive for Vibrio spp. The prevalence of Vibrio spp observed in this study is higher than those reported in previous studies [6 and 20\%] conducted in Burkina Faso [30] and Tanzania [31]. Thus, Vibrio spp isolated from water in this study is often the leading cause of human diarrhea.

A waterborne infection, cholera is spread by ingesting food or water contaminated with the bacteria [32]. In this study, the presence of Salmonella spp. [28.18\%] and Escherichia coli $[23.18 \%]$ in the water samples indicates continuous fecal [Human and animal] contamination [13].
Human droppings may be predominant because during samples collection, it was observed areas of peoples frequently defecate in the wild. It is noted that the latrines and waste dumps are located in the immediate environment of some lakes, lagoon, and rivers sampled. Under these conditions, the contamination of the waters of lakes, lagoons and rivers by rejected excreta is favored by runoff and infiltration of rainwater [33].

Three species including Vibrio alginolyticus, Vibrio. Parahaemolyticus, and Vibrio cholerae non 01 [35\%] were molecularly identified. There are $32.56 \%$ of unidentified Vibrio strains. This work showed that the biochemically identified strains of $V$. parahaemolyticus were not all confirmed by PCR. Of the 28 biochemically identified isolates, 12 were identified as $V$. alginolyticus, 16 were identified as Vibrio parahaemolyticus by PCR. It is therefore evident that the PCR technique used offers better specificity than the phenotypic methods for differentiating these species of vibrios. The specificity and sensitivity of the PCR technique, compared to the conventional culture method, for the determination of pathogenic vibrios have been reported by several studies ${ }^{[15,21,34-36]}$.

The genes encoding the cholera toxin [ctxA and ctxB] were detected in the strains isolated during our study. Our results are contrary to those obtained in Côte d'Ivoire [37]. Those authors found that $V$. cholerae non-01 and non-0139 do not produce ctxA gene. In contrast, over $95 \%$ of strains belonging to non-01 / non-0139 serogroups do not produce CT or TCP [38].

A study conducted by Theophilo et al. ${ }^{[38]}$ detected ctxA gene in only $4.5 \%$ of their strains, which is in agreement with the toxigenic profile of $V$. cholerae.

It has been suggested that most strains of $V$. cholerae, especially those from the environment, lack the genes necessary to produce CT and the possibility of genetic exchange in the environment allows the potential emergence of new toxigenic clones [39]. The horizontal gene transfer plays an important role in increasing the genetic variability of bacterial species and confers new phenotypes, such as virulence, on the recipient ${ }^{[40-41]}$.

The emergence of new toxigenic strains of Vibrio cholerae and their selective enrichment during cholera epidemics constitute essential mechanisms for the survival and development of Vibrio cholerae and genetic elements that ensure the transfer of virulence genes ${ }^{[42]}$.

Strains of Vibrio cholerae may produce unknown virulence factors [39]. 
Faruque et al. [39] observed that non-01 non-0139 V. cholerae strains colonize and can cause fluid accumulation in rabbits despite the absence of the genes encoding TCP and CT. However, we cannot conclude that the non-01 Vibrio cholerae species that we have isolated do not possess the ctx genes, are not potentially pathogenic and do not pose a risk to human health.

In fact, approximately $70 \%$ of non-01 Vibrio cholerae strains have a polysaccharide capsule, made up entirely of sugars that increases the ability of bacteria to resist phagocytosis and to cause sepsis in immunosuppressed subjects ${ }^{[43-45]}$.

In our study, the prevalence of $V$. parahaemolyticus in water is $5 \%$, which is similar to the figure of $5 \%$ reported by Bouchriti et al. [46]. The genes encoding major virulence factors the direct thermostable and delayed thermostable hemolysins of Vibrio parahaemolyticus [tdh and trh] were detected in a few strains isolated during our study. Hemolysis, which is due to direct heat-stable hemolysin $\mathrm{TDH}$, distinguishes positive Kanagawa [virulent] strains from negative Kanagawa strains [a-virulent]. However, the existence of negative Kanagawa strains has been shown which have occasionally been associated with outbreaks of gastroenteritis ${ }^{[4]}$.

Vibrio alginolyticus is one of the most common and frequent species of vibrios, living freely in water and sediments, even under unfavorable conditions the latter retain their virulence. They are opportunistic pathogens whose pathogenicity is considered similar to that of Vibrio parahaemolyticus [48]. In our study, the strains of Vibrio alginolyticus were isolated during the rainy season [June October] at a prevalence of $4.55 \%$ of the water; this could be attributed to the favorable environmental conditions, in particular the increase in temperature and salinity that promote the multiplication and transmission of this germ.

All the $V$. cholerae non-01 strains isolated from water produced a zone of hemolysis on sheep blood agar which is in fact due to hemodigestion [protease and lecithinase], but it is only the biovor El Tor which is hemolytic.

\section{Conclusion}

Our study identified 51 strains of Vibrio isolated from the waters and revealed that they belong to three species of Vibrio. Two of those species [V. cholerae and $V$. parahaemolyticus] are associated with gastrointestinal diseases. In addition, genes encoding the main virulence factors were detected in strains of $V$. cholerae. However, it was detected in V. parahaemolyticus. However, our results revealed considerable contamination of water with Vibrio spp., which could represent a risk to human health.

\section{Acknowledgments}

We address our sincere thanks to the health actors, community workers, the exposed population and those who assisted us in carrying out this work.

\section{Data Availability Statement}

The data are available from the corresponding author upon request.

\section{Declaration of Interests}

The authors declare there is no competing interests about the publication of this manuscript.

\section{REFERENCE}

1. Echenberg M. Africa in the Time of Cholera: A History of Pandemics from 1817 to the Present. Emerg Infect Dis. 2012 Feb; 18(2): 362. [DOI: 10.3201/eid1802.111535].

2. Glass RI, Claeson M, Blake PA, Waldman RJ, Pierce NF. Cholera in Africa: lessons on transmission and control for Latin America. Lancet. 1991 Sep 28; 338(8770):791-5. [DOI: 10.1016/0140-6736(91)90673-d].

3. Andrews JR, Basu S. Transmission dynamics and control of cholera in Haiti: an epidemic model. Lancet. 2011 Apr 9; 377(9773):1248-55. [DOI: 10.1016/S0140-6736(11)60273-0].

4. Altizer $S$, Dobson $A$, Hosseini $P$, Hudson $P$, Pascual $M$, Rohani $P$. Seasonality and the dynamics of infectious diseases. Ecol Lett. 2006 Apr; 9(4):467-84. [DOI: 10.1111/ j.1461-0248.2005.00879.x].

5. Moore S, Dongdem AZ, Opare D, Cottavoz P, Fookes M, Sadji AY, et al. Dynamics of cholera epidemics from Benin to Mauritania. PLoS Negl Trop Dis. 2018 Apr 9; 12(4):e0006379. [DOI: 10.1371/journal.pntd.0006379].

6. Kwok AY, Wilson JT, Coulthart M, Ng LK, Mutharia L, Chow AW. Phylogenetic study and identification of human pathogenic Vibrio species based on partial hsp60 gene sequences. Can J Microbiol. 2002 Oct; 48(10):903-10. [DOI: 10.1139/w02-089. PMID: 12489780].

7. Thompson $\mathrm{FL}$, lida $\mathrm{T}$, Swings J. Biodiversity of vibrios. Microbiol Mol Biol Rev. 2004 Sep; 68(3):403-31. [DOI: 10.1128/MMBR.68.3.403-431.2004].

8. Farmer lii JJ, Michael Janda J, Brenner FW, Cameron DN, Birkhead KM. Vibrio. In: Bergey's Manual of Systematics of Archaea and Bacteria. Farmer lii JJ, Michael Janda J, Brenner 
FW, Cameron DN, Birkhead KM [eds]. John Wiley \& Sons, Inc., in association with Bergey's Manual Trust 2015, pp 1-79.

9. Lamrani Alaoui H, Oufdou K, Mezrioui NE. Determination of several potential virulence factors in non-01 Vibrio cholerae, Pseudomonas aeruginosa, faecal coliforms and streptococci isolated from Marrakesh groundwater. Water Sci Technol. 2010; 61(7):1895-905. [DOI: 10.2166/wst.2010.263] .

10. Lipp EK, Huq A, Colwell RR. Effects of global climate on infectious disease: the cholera model. Clin Microbiol Rev. 2002 Oct; 15 (4):757-70. [DOI: 10.1128/CMR.15.4.757770.2002].

11. UNICEF. Benin Ministry of Health, epidemiological surveillance data 2004-2013, cholera epidemiology and response. 2014; https://www.unicef.org/cholera/files/UNICEFCholera_Factsheet-Benin-VF.pdf

12. Madoroba E, Momba MN. Prevalence of Vibrio cholerae in rivers of Mpumalanga province, South Africa as revealed by polyphasic characterization. Afr J Biotechnol, 2010; 9[43]: 7295-7301. [DOI: 10.5897/AJB10.321].

13. Rodier J, Bazin C, Broutin JP, Champsaur H, Rodi L. Water analysis: natural waters, residual waters, seawaters. Dunod

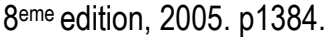

14. Dashti AA, Jadaon MM, Abdulsamad AM, Dashti HM. Heat treatment of bacteria: a simple method of DNA extraction for molecular techniques. Kuwait Med J. 2009 ; 41[2] : 117-122.

15. Lee $\mathrm{CY}$, Pan SF, Chen $\mathrm{CH}$. Sequence of a cloned pR72H fragment and its use for detection of Vibrio parahaemolyticus in shellfish with the PCR. Appl Environ Microbiol. 1995 Apr; 61(4):1311-7. [DOI: 10.1128/aem.61.4.1311-1317.1995].

16. Chun J, Huq A, Colwell RR. Analysis of 16S-23S rRNA intergenic spacer regions of Vibrio cholerae and Vibrio mimicus. Appl Environ Microbiol. 1999 May; 65(5):2202-8. [DOI: 10.1128/AEM.65.5.2202-2208.1999].

17. Kim YB, Okuda J, Matsumoto C, Takahashi N, Hashimoto S, Nishibuchi M. Identification of Vibrio parahaemolyticus strains at the species level by PCR targeted to the toxR gene. J Clin Microbiol. 1999 Apr; 37(4):1173-7. [DOI: 10.1128/JCM. 37.4.1173-1177.1999].

18. Robert-Pillot A, Guenole A, Fournier JM. Usefulness of R72H PCR assay for differentiation between Vibrio parahaemolyticus and Vibrio alginolyticus species: validation by DNA-DNA hybridization. FEMS Microbiol Lett. 2002 Sep 24; 215(1):1-6. [DOI: 10.1111/j.1574-6968.2002.tb11362.x].

19. Fields PI, Popovic T, Wachsmuth K, Olsvik O. Use of polymerase chain reaction for detection of toxigenic Vibrio cholerae 01 strains from the Latin American cholera epidemic. J Clin Microbiol. 1992 Aug; 30(8):2118-21. [DOI: 10.1128/jcm.30.8.2118-2121.1992].

20. Olsvik O, Wahlberg J, Petterson B, Uhlén M, Popovic T, Wachsmuth IK, Fields PI. Use of automated sequencing of polymerase chain reaction-generated amplicons to identify three types of cholera toxin subunit $B$ in Vibrio cholerae 01 strains. J Clin Microbiol. 1993 Jan; 31(1):22-5. [DOI: 10.1128/jcm.31.1.22-25.1993].

21. Panicker G, Call DR, Krug MJ, Bej AK. Detection of pathogenic Vibrio spp. in shellfish by using multiplex PCR and DNA microarrays. Appl Environ Microbiol. 2004 Dec; 70 (12):7436-44. [DOI: 10.1128/AEM.70.12.7436-7444.2004].

22. Lê $\mathrm{S}$, Josse J, Husson F. FactoMineR: an $\mathrm{R}$ package for multivariate analysis. J Stat Softw $2008 ; 25[1]$ : 1-18. [DOI : 10.18637/jss.v025.i01].

23. Pinheiro J, Bates D, DebRoy S, Sarkar D. The R Development Core Team. 2017. nIme: linear and nonlinear mixed effects models. R package version 3.1-131.

24. Issola Y, Kouassi AOM, Dongu BK, Biemi J. Caractéristiques physico-chimiques d'une lagune côtière tropicale : lagune de Fresco [Côte d'Ivoire]. Afr Sci. 2008; 04[3] 368-393. [DOI: 10.4314/afsci.v4i3.61696].

25. Boko M, Kosmowski F, Vissin E. [Les Enjeux du Changement Climatique au Bénin]. Konrad-Adenauer-Stiftung 2012 : p 72.

26. Duarte CM, Hendriks IE, Moore TS, Olsen YS, Steckbauer A, Ramajo $\mathrm{L}$, et al. Is ocean acidification an open-ocean syndrome? Understanding anthropogenic impacts on seawater pH. Estuaries and Coasts 2013 ; 36[2] : 221-236. [DOI 10.1007/s12237-013-9594-3].

27. Konan SK, Kouassi AM, Adingra AA, Dongui BK, Gnakri D. [Variations saisonnières des paramètres abiotiques des eaux d'une lagune tropicale: la lagune de Grand-Lahou, Côte d'Ivoire]. Eur J Sci Res. 2008; 21[3], 376-393.

28. Chagas GG, Suzuki MS. Seasonal hydrochemical variation in a tropical coastal lagoon. Braz J Biol. 2005 Nov; 65(4):597607. [DOI: 10.1590/s1519-69842005000400006].

29. Igbinosa EO, Okoh Al. Toxigenic Vibrio cholerae strains and their associated malaises. Afr J Microbiol Res 3[5]: 200-211. [DOI: 10.5897/AJMR.9000713].

30. Traoré O, Martikainen $\mathrm{O}$, Siitonen A, Traoré AS, Barro N, Haukka K. Occurrence of Vibrio cholerae in fish and water from a reservoir and a neighboring channel in Ouagadougou, Burkina Faso. J Infect Dev Ctries. 2014 Oct 15; 8(10):1334-8. [DOI: $10.3855 /$ jidc.3946].

31. Mdegela RH, Mhongole OJ, Kamundia PW, Byarugaba D, Mbuthia PG. Identification of Salmonela and Vibrio in water 
and Oreochromis niloticus in Mwanza Gulf, Lake Victoria, Tanzania. Int J Curr Res. 2015; 7 [7]: 18087-18092.

32. WHO 2011. World Health Organization. Cholera Fact sheet Number 107. http://www.who.int/mediacentre/factsheets/fs 107/en/ index.html

33. Haijoubi EH, Benyahya F, Bendahou A, Essadqui FZ, Behhari $\mathrm{ME}$, El Mamoune AF, et al. Etude de la qualité bactériologique de l'eau utilisée dans l'industrie agroalimentaire dans le Nord du Maroc [Study of the bacteriological quality of water used in the agro-food industry in the North of Morocco]. Pan Afr Med J. 2017; 26:13. French. [DOI: 10.11604/pamj.2017.26.13. 10591].

34. González SF, Krug MJ, Nielsen ME, Santos Y, Call DR. Simultaneous detection of marine fish pathogens by using multiplex PCR and a DNA microarray. J Clin Microbiol. 2004 Apr; 42(4):1414-9. [DOI: 10.1128/JCM.42.4.1414-1419.2004].

35. Gubala AJ, Proll DF. Molecular-beacon multiplex real-time PCR assay for detection of Vibrio cholerae. Appl Environ Microbiol. 2006 Sep; 72(9):6424-8. [DOI: 10.1128/AEM. 02597-05].

36. Cai T, Jiang L, Yang C, Huang K. Application of real-time PCR for quantitative detection of Vibrio parahaemolyticus from seafood in eastern China. FEMS Immunol Med Microbiol. 2006 Mar; 46(2):180-6. [DOI: 10.1111/j.1574-695X.2005. 00016.x].

37. Bertin TK, Nathalie GK, Jean-Claude AB, Raphaël OK, Eloge $\mathrm{E}$, Antoinette $\mathrm{AA}$, et al. Caractérisation Moléculaire des Souches de Vibrio Cholerae Non 01, Non 0139 Isolées des Eaux Lagunaires de Grand-Lahou (Côte d'Ivoire) [Molecular Characterization of Non 01, Non 0139 Vibrio Cholerae Strains Isolated from Lagoon Waters of Grand-Lahou (Côte d'Ivoire)]. Euro J Sci Res. 2010; 45(3): 333-345.

38. Theophilo GN, Rodrigues Ddos P, Leal NC, Hofer E. Distribution of virulence markers in clinical and environmental Vibrio cholerae non-01/non-0139 strains isolated in Brazil from 1991 to 2000. Rev Inst Med Trop Sao Paulo. 2006; 48(2):65-70. [DOI: 10.1590/s0036-46652006000200002].

39. Faruque SM, Chowdhury N, Kamruzzaman M, Dziejman M, Rahman MH, Sack DA, Nair GB, Mekalanos JJ. Genetic diversity and virulence potential of environmental Vibrio cholerae population in a cholera-endemic area. Proc Natl Acad Sci U S A. 2004 Feb 17; 101(7):2123-8. [DOl: 10.1073/pnas.0308485100].
40. Juhas M, Crook DW, Hood DW. Type IV secretion systems: tools of bacterial horizontal gene transfer and virulence. Cell Microbiol. 2008 Dec; 10(12):2377-86. [DOI: 10.1111/j.14625822.2008.01187.x].

41. Dorman CJ. H-NS-like nucleoid-associated proteins, mobile genetic elements and horizontal gene transfer in bacteria. Plasmid. 2014 Sep; 75: 1-11. [DOI: 10.1016/j.plasmid. 2014.06.004].

42. Faruque SM, Albert MJ, Mekalanos JJ. Epidemiology, genetics, and ecology of toxigenic Vibrio cholerae. Microbiol Mol Biol Rev. 1998 Dec; 62 (4): 1301-14. [DOI: 10.1128/ MMBR.62.4.1301-1314.1998].

43. Zhang XH, Austin B. Haemolysins in Vibrio species. J Appl Microbiol. 2005; 98(5):1011-9. [DOI: 10.1111/j.1365-2672. 2005.02583.x].

44. Cohen N, Karib H. [2007]. Vibrio spp dans les produits de la pêche: Risques et prévention [Vibrio spp. in the fishery products: Risks and prevention] [Les Technologies de Laboratoire] Laboratory Technologies 2007 ; 3: 4-10

45. Saka HA, Bidinost C, Sola C, Carranza P, Collino C, Ortiz S, Echenique JR, Bocco JL. Vibrio cholerae cytolysin is essential for high enterotoxicity and apoptosis induction produced by a cholera toxin gene-negative $\mathrm{V}$. cholerae non-01, non-0139 strain. Microb Pathog. 2008 Feb; 44(2):118-28. [DOI: 10.1016/j.micpath.2007.08.013].

46. Bouchriti N, Hamouda A, Karib H, Oumokhtar B, Yaakoubi I. Appréciation de la qualité bactériologique des huîtres Crassostrea gigas commercialisées à Rabat [Assessment of the bacteriological quality of Crassostrea gigas oysters marketed in Rabat]. Animalis $2001 ; 2: 26-35$.

47. Fournier JM, Quilici ML. Choléra [Cholera]. Presse Med. 2007 Apr; 36(4 Pt 2):727-39. French. [DOI: 10.1016/j.Ipm.2006. 11.029].

48. Adebayo-Tayo BC, Okonko IO, Esen CU, Odu NN, Onoh CC, Igwiloh NJP. Incidence of potentially pathogenic Vibrio spp in fresh seafood from Itu Creek in Uyo, Akwa Ibom State, Nigeria. World Appl Sci J. 2011; 15[7]: 985-991 

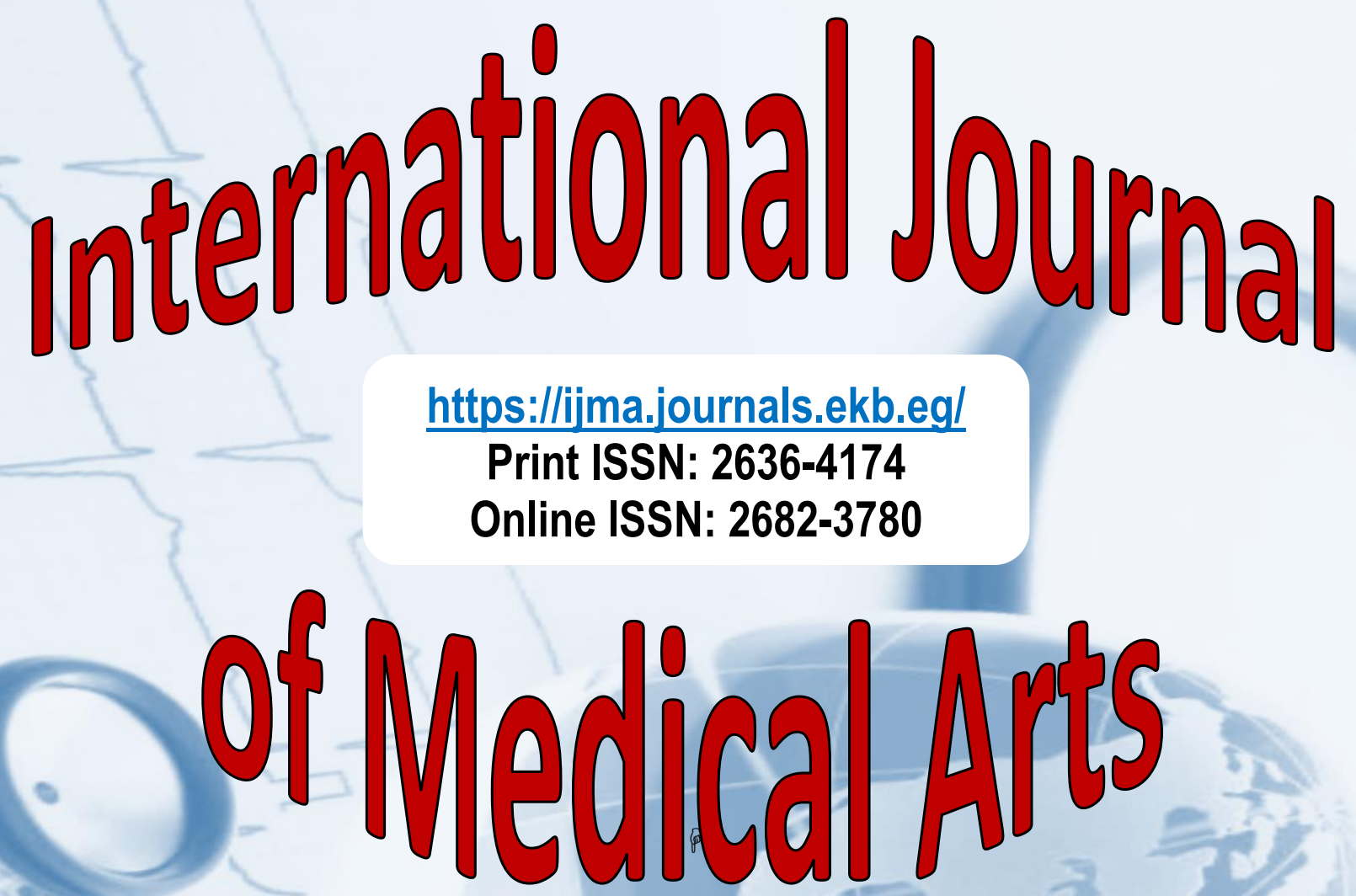